\title{
1987 年千葉県東方沖地震の地震動応答スペクトルにみられる 地盤特性の評価 \\ EVALUATION OF SITE EFFECTS ON RESPONSE SPECTRA OF GROUND MOTIONS OBSERVED DURING THE 1987 CHIBA-KEN-TOHO-OKI EARTHQUAKE
}

\author{
翠川三 郎*，作川孝一** \\ Saburoh MIDORIKAWA and Koichi SAKUGAWA
}

\begin{abstract}
Site effects on response spectra of ground motions observed at 173 sites during the 1987 Chibaken-toho-oki earthquake $(M=6.7)$ were evaluated. The results indicate that 1$)$ the site effects are significant on motions with periods longer than 0.2 second, 2) geomorphological land classification is more appropriate for evaluating the site effects than soil classification or surface geology, 3 ) the site amplifications at longer periods have stronger dependence on the average shear-wave velocity of ground, and 4) the average shear-wave velocity is a useful predictor for the site amplifications at periods of 0.7 to 1.5 seconds.
\end{abstract}

Keywords : strong ground motion, site effect, response spectrim, geomorphological land classification, average shear-wave velocity, the 1987 Chiba-ken-toho-oki earthquake 強震動，地盤特性，応答スペクトル，地形分類，平均 S 波速度，1987 年千葉県東方沖 地震

1.はじめに

近い将来発生するであろう地震動の特性をあらかじめ 予測しておくことは構造物の耐震設計上かつ地震防災対 策上重要な問題のひとつである。地震動の強さの尺度と しては最大振幅や応答スペクトルなどが用いられるが, 構造物の振動解析の際には応答スペクトルを用いたモー ド解析法がよく用いられる。そこで，観測された強震記 録を用いて，応答スペクトルの特性に及ぼす地震規模や 地盤条件の影響が統計的に解析されてきだー

これらの解析では, 地盤条件は地盤種別や表層地質に より大まかに分類され，各地盤分類での応答スペクトル 特性の違いが示されている。しかし，これらの地盤分類 は利用できる地盤の情報に基づいて分類されたもので， これらが地震動に及ぼす地盤の影響を評価するための最 良の分類法とは限らないことも指摘されている31,4),6)。

筆者らは, 1987 年干葉県東方沖地震の多数の強震記 録を用いて，地盤条件が地表面最大加速度および最大速 度に及ぼす影響を評価する際には，従来用いられている 地盤種別や表層地質よりも表層地質を地形分類で細分類
した地盤分類を用いるのがより適当であることを示し だ!。本研究では, 前報》で用いた 1987 年千葉県東方沖 地震の強震記録を用いて，その応答スペクトルにみられ る地盤特性の定量的評価を試みた。

\section{1987 年千葉県東方沖地霞の強霞記録}

1987 年干葉県東方沖地震は M 6.7 の中規模地震で, この地震の最大震度は勝浦, 千葉, 銚子でのVであり, 住家の一部破損などの被害が千葉県東部で多くみられ $た^{8)}$ 。解析に用いた強震記録は 31 機関により観測され た 173 地点でのものである。図一1に示すように，これ らの地点は千葉県, 茨城県, 埼玉県, 東京都, 神奈川県, 静岡県に分布しているが，東京湾沿岸に集中して分布し ている。観測点の地盤条件は岩盤から埋立地盤までさま ざまである。距離は $25 \mathrm{~km} \sim 180 \mathrm{~km}$ に分布しており, 50 100 km のものが比較的多い。なお，ここでは距離 の定義として断層面 ${ }^{9}$ からの最短距離を採用した。

各地点で用いられている地震計はさまざまであるた め，地震計の特性補正を行った。前報”と同様に，ノイ
* 東京工業大学総理工社会開発工学専攻 助教授 博士 (工学)

** 東京工業大学総理工社会開発工学専攻 大学院生
Assoc. Prof, , Dept. of Environmental Eng., Interdisciplinary Graduate School of Science and Engineering, Tokyo Institute of Technology, Dr. Eng.

Graduate Student, Dept. of Environmental Eng., Interdisciplinary Graduate School of Science and Engineering, Tokyo Institute of Technology 


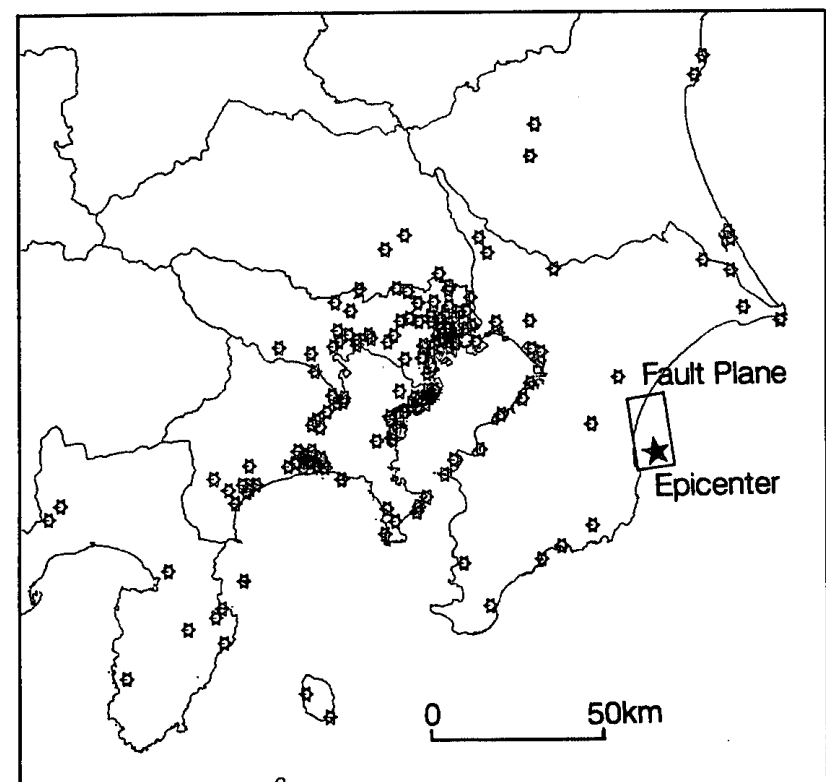

図一1 1987 年千葉県東方沖地霞の震央, 断層面の位置および 強震観測点の分布

ズ成分を除去するために，周期 0.1 秒から 3.5 秒まで平 坦で，周期 0.06 秒以下と 7 秒以上を完全に遮断するバ ンドパスフィルターを周波数領域でかけた。これらの処 理を行った後, 速度記録についてはさらに数值微分して 加速度記録を求めた。補正された加速度記録の最大値は $9 \sim 430 \mathrm{~cm} / \mathrm{s}^{2}$ に分布し, 大部分は $30 \sim 200 \mathrm{~cm} / \mathrm{s}^{2}$ の範囲 にある。また, 最大速度振幅では大部分が $3 \sim 20 \mathrm{~cm} / \mathrm{s}$ の範囲にある7”。最大速度が $20 \mathrm{~cm} / \mathrm{s}$ 程度を超えないと 地盤の非線形性の影響は影著に現れないこと影功こ れらのデータの解析結果には地盤の非線形性の影響はあ まり含まれないものと考えられる。

応答スペクトルは，地震動の方向性を考虑して，2 次 元応答スペクトルの形で計算した"11)。すねち，水平 2 成分の加速度記録に対して一質点系の絶対加速度応答の 時刻歴をそれぞれ計算し，それらの 2 乗和の平方根の最 大值加絶対加速度応答スペクトルを求めた。減衰定数 は $5 \%$ とし，周期 0.1 - 秒の範囲で計算した。

\section{3. 各地盤分類における地盤の增幅率}

地震動の特性を支配する要因として,地盤条件の他に, 震源特性之伝播経路特性がある。震源特性のひとつとし て，震源からの方位依存性が指摘されているが，この地 震の記録の最大振幅には方位依存性の影響は無視できる もの之考えられる7)。そこで，伝播経路特性の主な要因 である距離減衰の影響を補正して応答スペクトルに及ぼ す地盤の影響を近似的に抽出することとした。

まず，観測点の地盤条件を地盤分類によって評価する こととし，地盤分類ごとに距離减衰式を求めて各地盤分 類での平均的な地盤の増幅率を評価した。用いたデー夕 のほとんぞは震源の大きさに比べて震源からの距離が大
表一1 用いた地盤分類と対応するデータの数

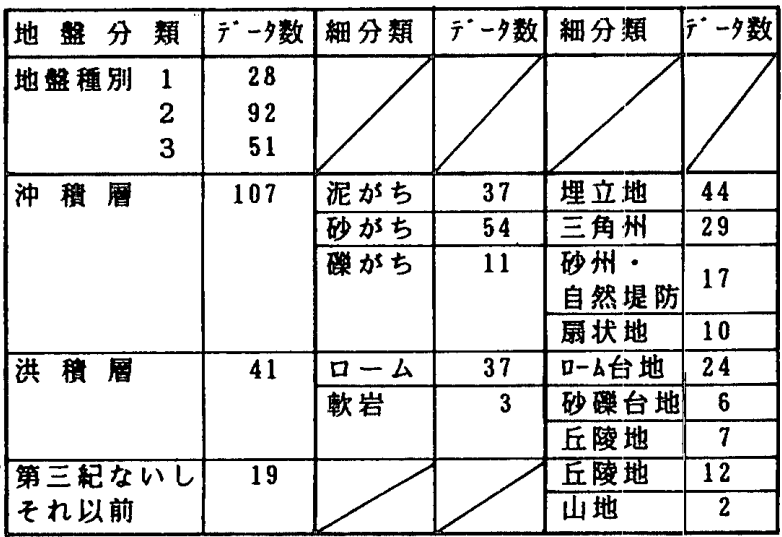

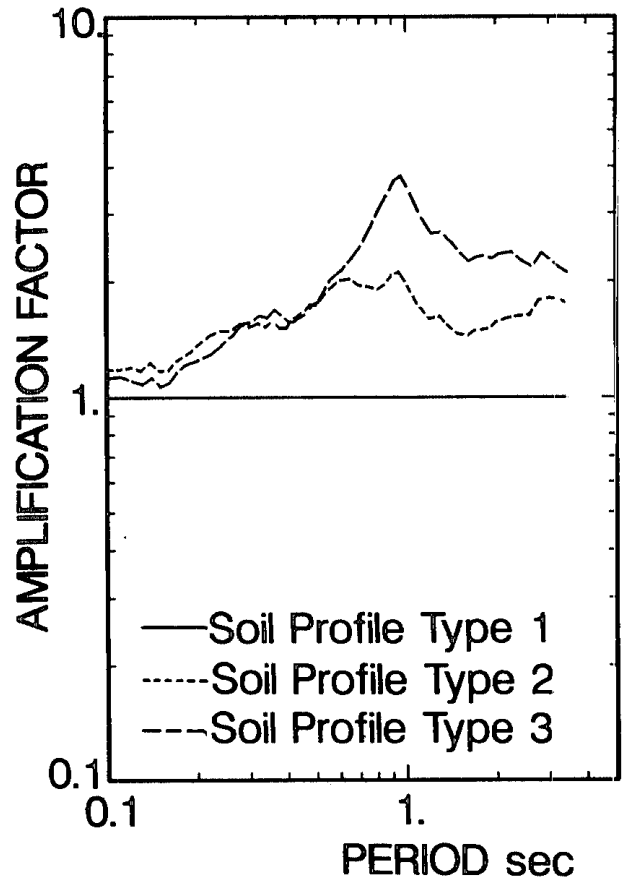

図一2 地盤種別ごとの地盤の増幅率

きいので，点震源を仮定した以下の式 ${ }^{12)} て ゙$ 絶対加速度応 答スペクトル $S_{A}(T)$ と距離 $X(\mathrm{~km})$ の関係を回帰分析 した。

$$
\log S_{A}(T)=C_{i}(T)-\log X-k(T) X
$$

ここで, $k(T)$ は伝播経路での粘性堿衰を表す項である。 $C_{i}(T)$ は補正項で,これを各地盤分類 $i$ に対して求めた。

地盤の分類として，しばしば用いられる地盤種別の他 に，地質区分，土質分類，地形分類も用いた。本研究で 用いた地盤種別は，建築基準法施行令による地盤種別の 定義に基づき，観測点のボーリング調查結果，各種地盤 図などを用いて著者らの責任で定めたものである。また， 各地点の地質区分等は国土庁土地分類図やそれに基づく 国土数値情報 ${ }^{13)}$ を利用して定めた。ただし，全 173 地点 の内，地盤種別ないし他の地盤分類のいずれかがわから なかった地点もわずかながらある。表一1に用いた地盤 
分類と対応するデー夕数を示す。

回帰分析より得られる各種地盤での補正項 $C_{i}(T)$ には 震源のスペクトル特性も含まれる。そこで, 各種地盤で の補正項から基準となる地盤でのそれを引いて基準化し た後，その真数をとつて各種地盤の増幅率を表すことと した。地盤種別で地盤分類し，1種地盤を基準とした場 合の結果を図一 2 に示す。周期 $0.1 \sim 0.15$ 秒では各地盤 種別の差はほとんどない。周期 0.15〜0.5 秒では 2 種地 盤と 3 種地盤の違いはほとんどないが，1 種地盤に対し て 1.5 倍前後の増幅率を示す。それより長い周期では, 2 種地盤では周期 0.6 1 秒で 2 倍程度の増幅を示すの に対し， 3 種地盤では周期約 1 秒で 4 倍弱の増幅率を示 す。2 種地盤に対する 3 種地盤の増幅率の比は 1.6 倍前 後である。

これらの結果を既往の研究の結果と比較して図一 3 に 示す。なお，片山ら の用いた地盤種別は道路橋耐震設 計指針に基づくもので，片山らの I 種地盤，II 種・III種 地盤および N 種地盤はそれぞれ本研究の 1 種地盤，2種 地盤および 3 種地盤におおむね相当する。本研究の結果 は，片山らの結果とおおむね一致する。3 種地盤の周期 1.5 秒以上の範囲では本研究の結果の方が大きいが, こ れは本研究では堆積層の厚い関東平野でのデー夕のみを 用いたためとも考えられる。図には，建築基準法の振動 特性係数を 1 種地盤のそれで基準化したものも示してあ る。これらは, 本研究の結果に比べて周期 $0.2 \sim 1.5$ 秒 程度の範囲で地盤の影響を小さく評価している傾向にあ

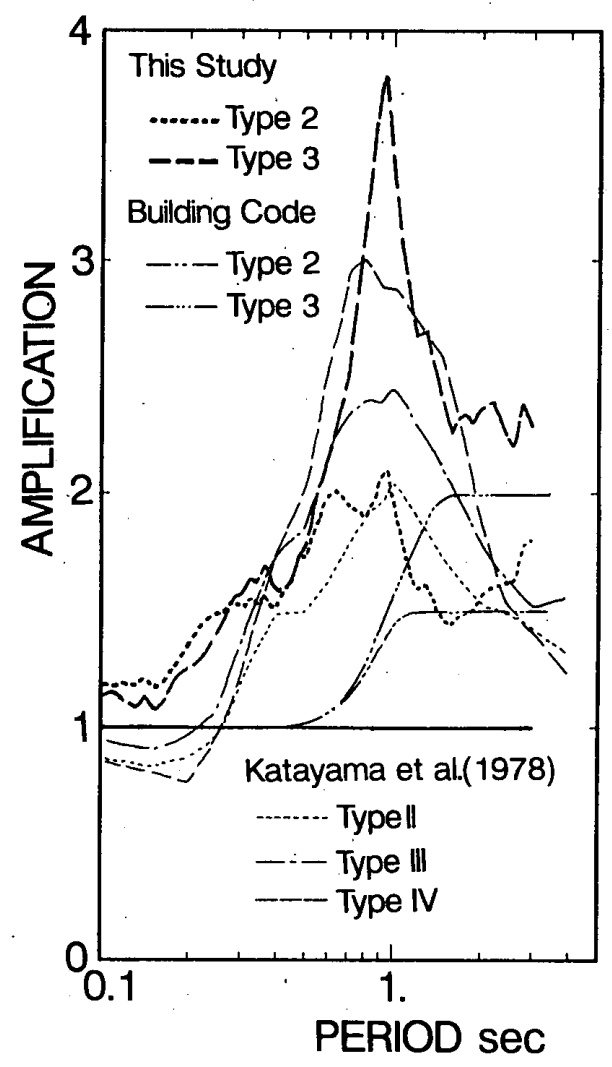

図一3地盤種別ごとの地盤の増幅率（既往の結果との比較）
るが,それ以外の周期では両者はおおむね対応している。 地質区分を用いて， 沖積地盤，洪積地盤，第三紀ない しそれ以前の地盤に地盤分類し，第三紀ないしそれ以前 の地盤を基準とした場合の増幅率を図一4 に示す。周期 0.1〜0.25 秒では沖積地盤と洪積地盤の差はほとんどな く, 1.5 倍前後の増幅率を示す。それより長い周期では, 洪積地盤では増幅率は周期によらず 1.5 倍前後の值を示 すのに対して, 沖積地盤では周期 1 秒で増幅率は 3 倍を 示し，洪積地盤に比べて最大で 2 倍の值を示す。

沖積地盤および洪積地盤を表層土質で細分類した場合 の増幅率を図一5に示す。沖積地盤では，砂がち（砂質）
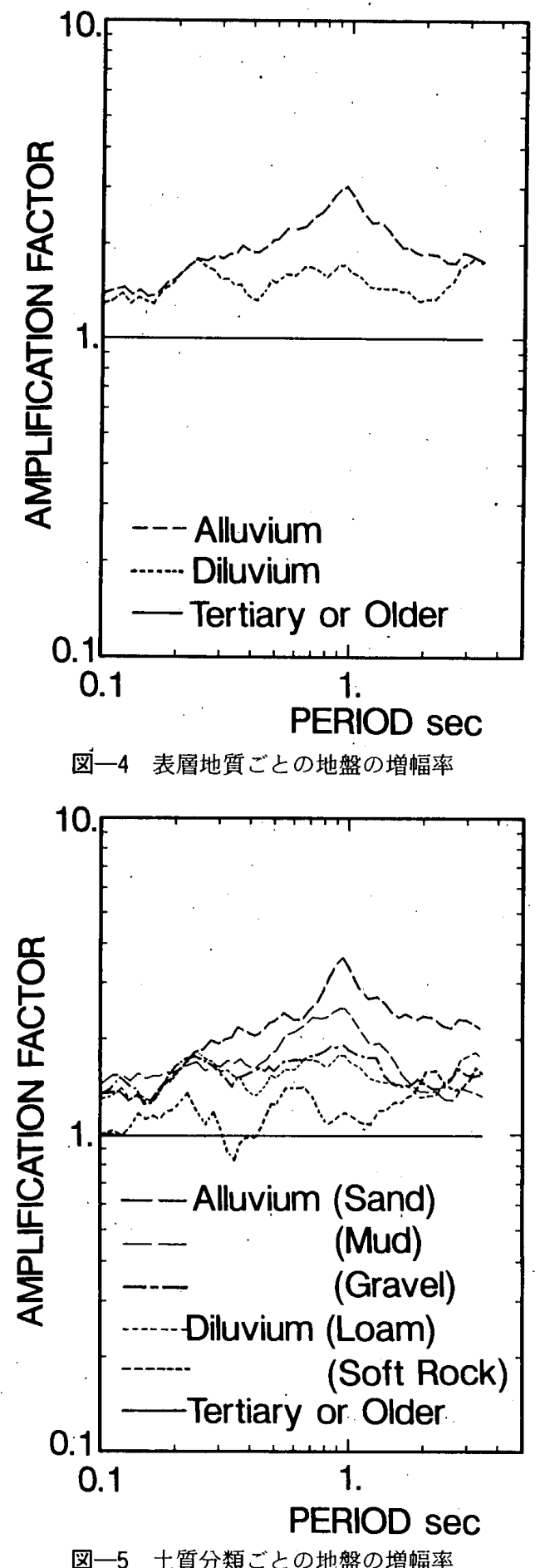


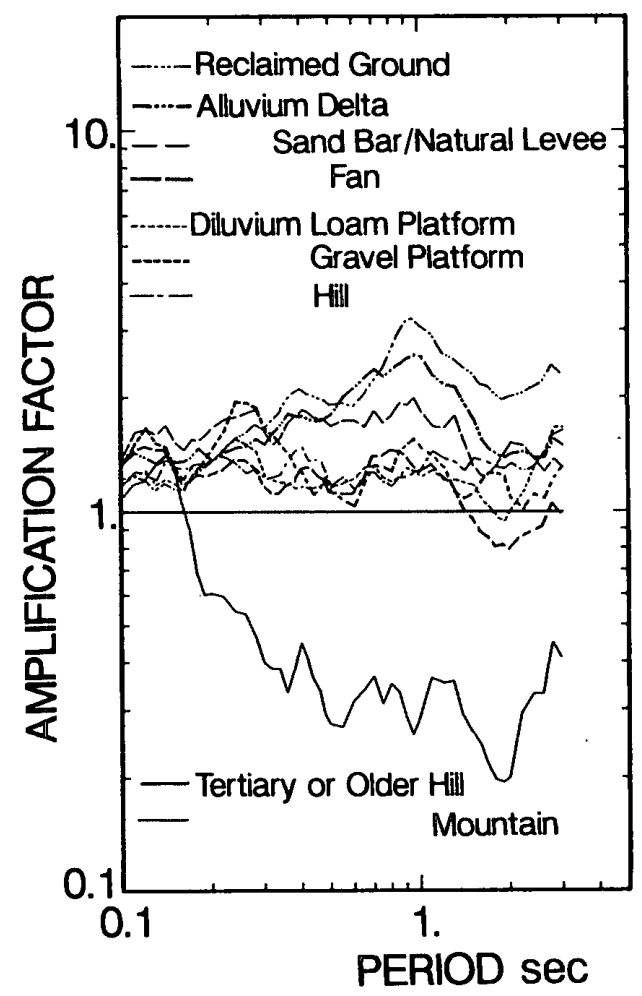

図-6 地形分類ごとの地盤の増幅率

地盤で増幅率が大きく，前述の 3 種地盤の場合とほぼ同 じ結果を示す．増幅率は泥がち（粘土質）地盤ではやや 小さく，喽がち（碩質）地盤ではさらに小さく，洪積の ローム地盤と同様に周期によらず 1.6 倍程度の值を示 す。洪積の軟岩では増幅率は小さく, $0.8 \sim 1.5$ の值を 示す。

沖積，洪積，第三紀ないしそれ以前の地盤を地形分類 で細分類した場合の増幅率を図一6に示す。第三紀ない しそれ以前の地盤である山地と丘陵地の内, 山地での データ数が少ないので,丘陵地を基準として示してある。 山地では周期 0.15 秒以下では増幅率は 1 をやや上回る が，周期が増大するにつれて増幅率は減少し，周期 0.5 秒以上では増幅率の大きい埋立地等に比べて $1 / 10$ 程度 の值を示す。洪積地盤では地形ごとの違いは小さく，増 幅率は周期によらず 1.3 程度の値を示す。沖積地盤の内, 扇状地では洪積地盤と同様の值を示し, 砂州・自然堤防, 三角州，埋立地の順で増幅率は増大していく。ただし， 周期 0.3 秒程度以下では地形ごとの違いはほとんどな $<, 1.5$ 前後の值を示す。いずれの地盤分類の場合でも， 地盤ごとの増幅率の違いは，短周期では小さく，長周期 で大きくなる傾向にある。

得られた回帰式による予測値に対する観測値の比を求 め，その対数の標準偏差を図一7に示す。地盤種別で分 類した場合と表層地質で分類した場合では標準偏差はほ とんどかわらない。表層地質を土質で細分類した場合に もあまり改善されない。地形で細分類した場合には，分 類数が 9 種類に増えたとはいえ，標準偏差はかなり小さ

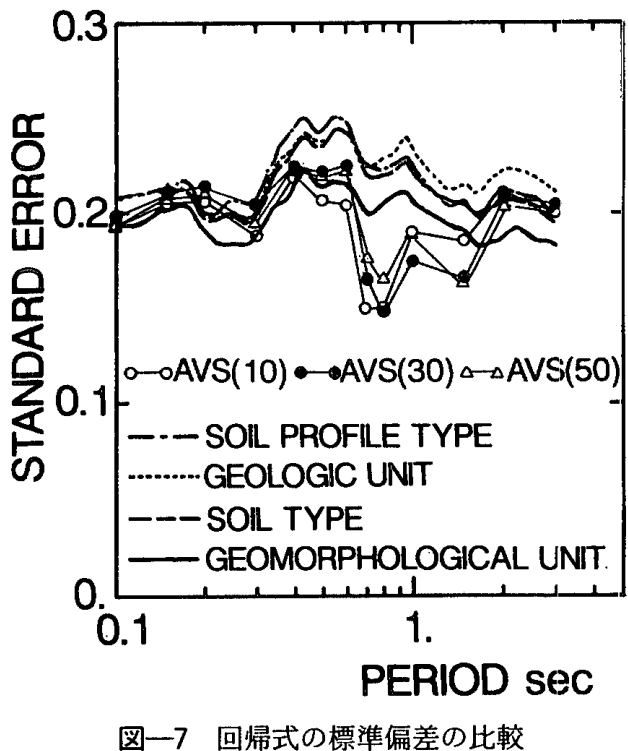

くなり，応答スペクトルに及ぼす地盤条件の影響を評価 するために地形分類がより適当であることを示唆してい る。

本研究で用いた土地分類図は国土調查法による土地分 類調査を各県別単位にまとめた中縮尺（10万ないし 20 万分の 1) のものである ${ }^{14)}$ 。国土調查法では，地形の成 因論で地形の分類項目が決められ，地形的に等質性のあ る広がりが受けた形成過程を基礎とした地形分類がなさ れている15\}。したがって，この地形分類は，単なる形態 的な分類ではなく，地盤の形成過程を反映したものであ り，ある程度の深さまでの地盤の構造を反映したものと 考えられる。

一般に, 山地, 丘陵地, 台地, 低地と, 標高が低くな るにつれて地盤が軟弱となり, 低地の中で沈, 扇状地, 自然堤防，三角州と，河川の下流で形成される地形ほど 軟弱となる ${ }^{(6)}$ 。実際, 深さ $30 \mathrm{~m}$ までの地盤の平均 $\mathrm{S}$ 波 速度は地形ごとにある程度まとまっており, 前述の順番 で各地形の地盤の平均 S 波速度は小さくなっている ${ }^{17) 。 ~}$ 地盤の平均 $\mathrm{S}$ 波速度は, 平均的には, 低地で 200 300 $\mathrm{m} / \mathrm{s}$, 台地で 300 400 m/s の值を示す。第三紀または それ以前の丘陵地は，そのほとんどが新第三紀の堆積地 盤で, 平均 $\mathrm{S}$ 波速度は平均的には $500 \mathrm{~m} / \mathrm{s}$ 程度と考えら れる ${ }^{17) 。}$

山地のデータは, 1 地点は古生代の岩盤上に, 他の 1 地点は新第三紀の火山岩上に位置し, $\mathrm{S}$ 波速度で 1 $\mathrm{km} / \mathrm{s}$ ないしそ机以上の硬い岩が地表近くに存在してい る。山地のデータは 2 地点のみで, これら 2 地点が山地 の地盤を代表している保証はないが, 山地に比へ丘陵地 では堆積作用がより強いため表層地盤の層厚がより厚い と考えられることや，山地では先第三紀の岩盤や硬質な 火山岩の占める割合が比較的多いことから，山地と丘陵 地で地盤の S 波速度に大きな相違が生ずることは一般的 


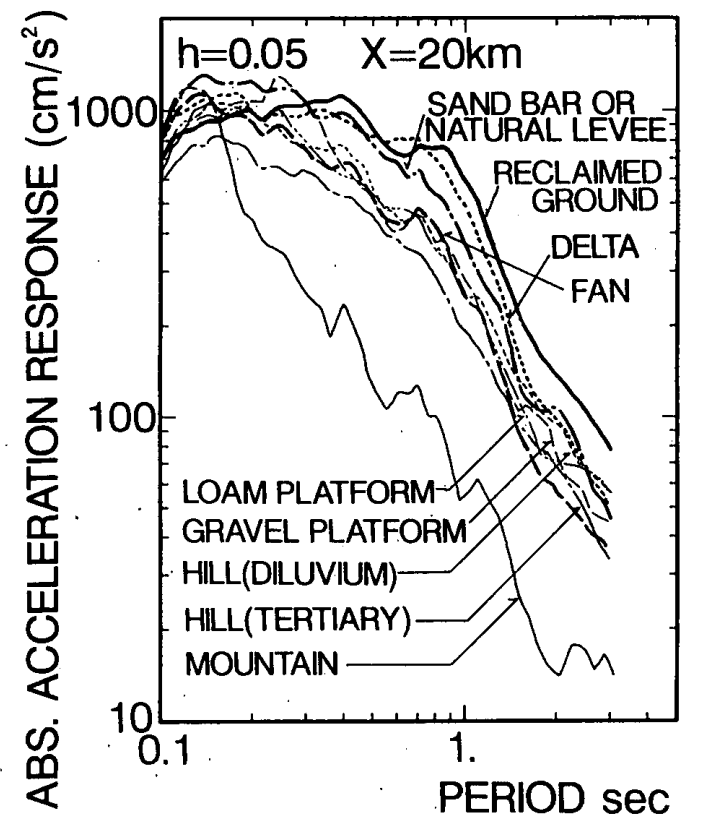

図一8＼cjkstart回州式による加速度応答スペクトル

とも考えられる。

後に述べる地盤の $\mathrm{S}$ 波速度と増幅率の相関から，この 地形ごとの地盤の $\mathrm{S}$ 波速度の違いは，低地から台地，丘 陵地になるにつれて增幅率が小さくなり，山地では大幅 に小さくなるという前述の結果を定性的にはよく説明し ており，地形分類が地盤の増幅率を評価する指標として 適当であることに一つの物理的根拠を与えるものであ る。

地形分類の場合に得られた回帰式に距離 $20 \mathrm{~km}$ を代 入して得られる応答スペクトルを図一8に示す。短周期 では砂州・自然堤防で振幅が大きく, 長周期では埋立地 で振幅が大きい。スペクトル形状は，埋立地や三角州で は周期 0.8 秒前後まで加速度応答量はおおむね一定であ るが, それ以外の沖積の地形や洪積の地形では周期 0.3 $\sim 0.5$ 秒以上で振幅は周期とともに娍少する。第三紀な いしそれ以前の地形では周期 $0.15 \sim 0.2$ 秒以上で振幅は 周期とともに減少する。

参考までに，各地盤分類を行った場合に得られた距離 減衰係数 $k(T)$ の值を図一 9 に示す。関東地域での地震 記録から得られた既往の減衰係数 $\left.{ }^{18)}, 19\right)$ も図に示してあ る。地盤種別, 表層地質, 土質分類の場合には $k(T)$ は おおむね周期によらず一定の傾向を示す。地形分類の場 合には，周期とともに減少する傾向がみられ，周期 0.3 秒以上では他の場合に比べ小さい。

用いた応答スペクトルと距離の関係にばらつきが小さ くないことや用いたデータの距離が比較的狭い範国に分 布していることから，今回の回㛿分析ではいずれの場合 にも得られた $k(T)$ の値の信頼性は高いとは言いにく い。そこで, どちらの傾向が実際の距離減衰特性を示し

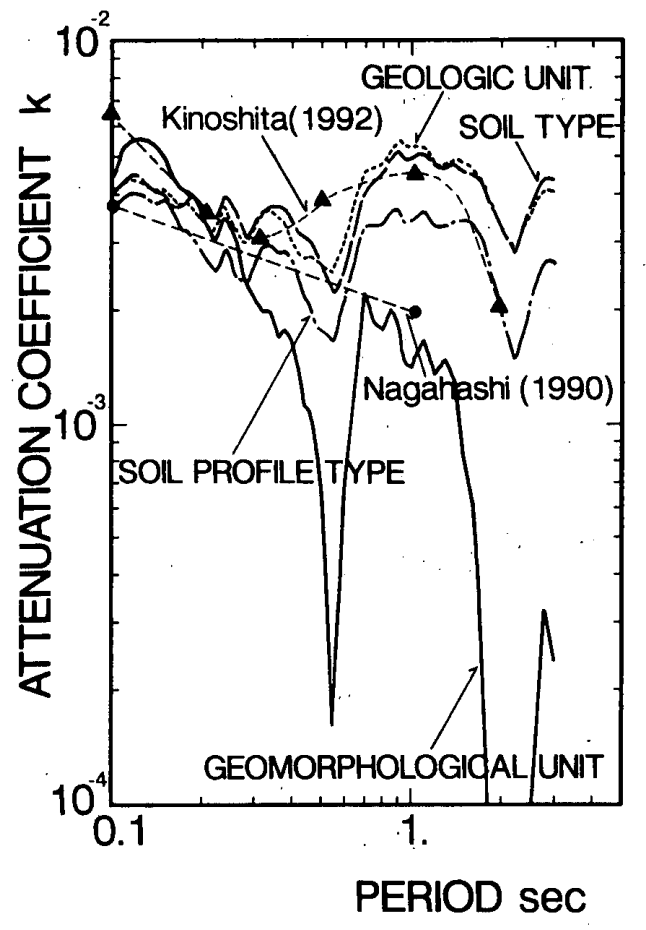

図-9 距離减衰係数 $k(T)$ の比較

ているのか断定するのは困難であるが，いずれの場合で も距離减衰係数の值は既往の結果と大きな隔たりはな い。なお，用いたデー夕の距離は， $80 \mathrm{~km}$ 程度を中心と して前後 $30 \mathrm{~km}$ に全体の約 $75 \%$ が分布することから, 距離減衰係数の值を多少変化させても得られる增幅率の 結果に大きな変化は生じないものと考えられる。

\section{4. 地盤の平均 $\mathrm{S}$ 波速度と地盤の增幅率の関係}

地震動に及ぼす地盤の影響と密接に関係する物理量と して, 地盤のS 波速度がある3”。従来より，地表からあ る梁さ $[d]$ までの地盤の平均 $\mathrm{S}$ 波速度 $[A V S(d)]$ が地 盤の増幅度を予測するための簡便な物理量であることが 指摘されている(7),201-23)，そこで，今回の記録を用いて 态答スペクトルから得られた増幅率に対する $A V S(d)$ の影響を定量的に検討した。

173 観測点のうち深さ $50 \mathrm{~m}$ までの S波速度構造が推 定可能な 41 地点について, $d$ を $10 \mathrm{~m}$ きざみで $10 \mathrm{~m}$ か ら $50 \mathrm{~m}$ に変化させて $A V S(d)$ を求めた。また, 第三紀 ないしそれ以前の丘陵地の距離減衰式からの值に対する 観測值の比 $R(T)$ を各周期 $T$ について求め, $A V S(d)$ と の関係が（2）式のように対数で線形関係になるものと 仮定して回帰式を求めた。

$$
\log R(T)=a(T) \log A V S(d)+b(T) \pm c(T)
$$

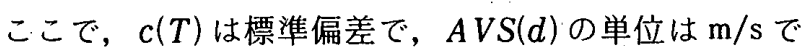
ある。各周期 $T$ について, $R(T)$ と各深さまでの $A V S$ (d) との回帰式を求め, 最も高い相関を示す $A V S S(d)$ の $d$ を最適深さと呼び, 最適梁さ $d$ での $A \dot{V} S(d)$ と $R(T)$ 
表一2 地盤の増幅率と平均 S 波速度の関係式の各係数

\begin{tabular}{|c|c|c|c|c|c|}
\hline 周期 & 係数 $\mathrm{a}$ & 係数 b & $\begin{array}{c}\text { 標洹侕差 } \\
\text { c }\end{array}$ & 相関係数 & $\begin{array}{c}\text { 最遮深さ } \\
\mathrm{d}(\mathrm{m})\end{array}$ \\
\hline 0.1 & -0.43 & 1.17 & 0.19 & 0.48 & 50 \\
\hline 0.15 & -0.26 & 0.72 & 0.21 & 0.41 & 10 \\
\hline 0.2 & -0.35 & 0.96 & 0.21 & 0.52 & 10 \\
\hline 0.3 & -0.47 & 1.20 & 0.19 & 0.66 & 10 \\
\hline 0.4 & -0.45 & 1.23 & 0.22 & 0.59 & 10 \\
\hline 0.6 & -0.55 & 1.44 & 0.20 & 0.70 & 10 \\
\hline 0.8 & -0.81 & 2.18 & 0.14 & 0.88 & 20 \\
\hline 1.0 & -0.98 & 2.68 & 0.17 & 0.85 & 30 \\
\hline 1.5 & -0.77 & 2.15 & 0.16 & 0.76 & 50 \\
\hline 2.0 & -0.62 & 1.72 & 0.20 & 0.60 & 50 \\
\hline 3.0 & -0.70 & 2.02 & 0.20 & 0.65 & 50 \\
\hline
\end{tabular}

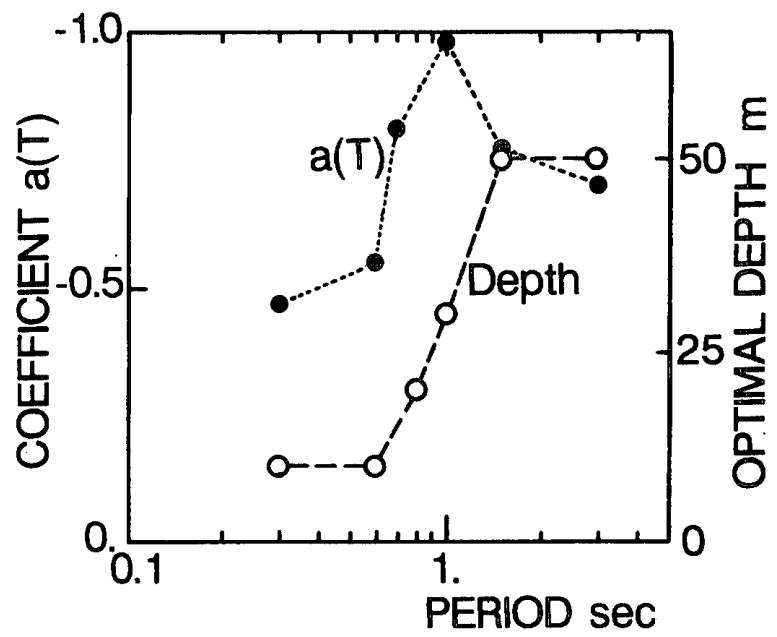

図一10 増幅率の平均 $\mathrm{S}$ 波速度依存性および最適深さと周期の 関係

について得られた各係数を表一 2 に示す。

相関係数が 0.65 を超える周期に着目すると, 図一 10 に示すように, 周期が長くなるほど,最適深さが深くなっ ている。これは，周期が長くなるほど，その周期領域を 支配する地震波の波長が長くなり，より深い地盤の影響 を受けることを示唆している。また，係数 $a(T)$ と周期 の関係はバラッキがみられるが, 全般的な傾向として $a(T)$ の絶対值は周期とともに増大している。

地盤の粘性減衰を無視すれば，増幅率は基盤に対する 地盤のインピーダンス比に反比例し，係数 $a(T)$ はほぼ -1 の值をとるものと期待される。解析結果は短周期に なるほどこれよりも絶対値が小さくなる。すなわち S 波 速度の変化に対して鈍感となる傾向を示す。これは，短 周期では地盤分類ごとの増幅率の違いが小さいという前 章での結果とも対応している。この理由として，既に指 摘されている ${ }^{24)}$ ように，地盤の粘性減衰によって短周期 では地盤の増幅が抑えられることが考えられる。

深さ $10 \mathrm{~m}, 30 \mathrm{~m}, 50 \mathrm{~m}$ までの平均 $\mathrm{S}$ 波速度と増幅率 の関係式の標準偏差を図一7にプロットした。深さによ る標準偏差の違いは比較的小さいが，周期 1 秒前後では
深さ $30 \mathrm{~m}$ の場合に偏差がやや小さい。各地盤分類の場 合の標準偏差と比較すると, 周期 0.7 秒から 1.5 秒の範 用では地形分類の場合に比べても標準偏差はかなり小さ く，この周期範囲では平均 S 波速度が増幅率を推定する 適当な指標であることがわかる。このことは最大速度に 対する地盤の増幅度と平均 S 波速度が強い相関を示すと いう既往の結果とよく対応する7),21!。それ以外の周期で は，地形分類の場合と同程度かやや大きな偏差を示し， 平均 $\mathrm{S}$ 波速度が格別有力な指標であるとは言いにくい。

\section{5. 結 論}

1987 年千葉県東方沖地震の際に 173 地点で得られた 強震記録の応答スペクトル特性に及ぼす地盤条件の影響 を検討し，以下の結論を得た。

1）各地盤での地盤の増幅率の相違は周期 0.2 秒以下で は小さいが，周期が長くなるにつれて地盤ごとの相違が 大きくなり，各地盤分類に対する平均的な増幅率の相違 は 10 倍程度にまで達する場合がある。

2）地盤の増幅率を評価するには，通常用いられている 地盤種別や地質区分よりは，地質区分を地形分類で細分 化した地盤分類を用いるのがより適当である。

3）地盤の増幅率は，周期が長くなるほど，より深い地 盤の平均 S 波速度に対して依存性がより強くなる㑯向に ある。

4）周期 $0.7 \sim 1.5$ 秒の範囲では，地盤の平均 $S$ 波速度 を用いると，地盤の増幅率をより精度良く評価できる。

\section{謝 辞}

本研究で用いた強震記録は，運輸省港湾技術研究所， 大林組, 科学技術庁防災科学技術研究所, 鹿島建設, 神 奈川県, 神奈川大学, 熊谷組, 建設省建築研究所, 建設 省土木研究所, 佐藤工業, 自治省消防研究所, 清水建設, 竹中工務店，鉄道総合技術研究所，電源開発，電力中央 研究所, 東急建設, 東京ガス, 東京工業大学, 東京大学 地震研究所, 同生産技術研究所, 東京電力, 東京都土木 研究所, 同港湾局, 同下水道局, 西松建設, 間組, フジ 夕, 三井建設, 三菱地所, 早稲田大学の各機関 (五十音 順）により観測されたものである。地形分類の意味・解 釈について早稻田大学若松加寿江氏よりご教示いただい た。本研究の一部は鹿島学術振與財団研究助成金によっ た。記して謝意を表する次第である。

\section{参考文献}

1）土田 肇ほか 3 名：各種地盤における平均忘答スペクト ル, 港㴒技術研究所報告, Vol. 12, No. 4, pp. 171 199, 1973.

2) Seed, H. B. et al. : Site-Dependent Spectra for Earthquake-Resistant Design, Bull. Seism. Soc. Am., Vol. 66, pp. 221 243, 1976.

3) Mohraz, B. : A Study of Earthquake Response Spectra 
for Different Geological Conditions, Bull. Seism. Soc. Am., Vol. 66, pp. 915 935, 1976.

4）片山恒雄, 岩崎敏男, 佐伯光昭 : 地震動加速度応答スペ クトルの統計解析, 土木学会論文報告集, No. 275, pp. 29 40, 1978.

5）川島一彦, 相沢 興, 高橋和之：最大地震動及び地震応 答スペクトルの距離減衰式, 土木研究所報告, 第 166 号, 1985.

6) Aki, K. : Local Site Effects on Strong Ground Motion, Earthquake Engineering \& Soil Dynamics II-Recent Advances in Ground-Motion Evaluation, ASCE, pp. 103 $\sim 155,1988$.

7) 翠川三郎, 松岡昌志, 作川孝一：1987 年千葉県東方沖地 震の最大加速度・最大速度にみられる地盤特性の評価, 日本建築学会構造系論文報告集，第 442 号, pp. 71 78, 1992.

8）望月利男ほか 3 名：1987 年千葉県東方神地震調查一震度 分布と被害の概要一, 総合都市研究, 第 35 号, pp. 5 31, 1988.

9）山田尚幸：体積歪計で観測された 1987 年 12 月 17 日千葉 県東方沖の地震, 地震学会講演予稿集, No. 1, p. 66, 1988.

10）時松孝次, 翠川三郎：地表で観測された強震記録から推 定した表層地盤の非線形性状, 日本建築学会構造系論文 報告集，第 388 号，pp. 131 137， 1988.

11）小林啓美，長橋純男：地表で観測された地震動の周期特 性から求めた地盤の增幅特性と地震基盤における地震動 の特性, 日本建築学会論文報告集, 第. 240 号, pp. 79 92, 1976.

12）武村雅之, 太田外気晴, 稗圑成人：地震動の平均応答ス ペクトルを評価する経験式の物理的基礎, 日本建築学会 構造系論文報告集，第 375 号, pp. 1 9， 1987.

13）国土厅計画調整局，国土地理院：国土数値情報，国土情 報シリーズ2，大蔵省印刷局，1987。
14）島 博保，奥園誠之，今村遼平：土木技術者のための現 地踏査, 鹿島出版, 1981.

15）大矢雅彦編：地形分類の手法と展開，古今書院， 1984.

16）池田俊雄：わかりやすい地艋地質学, 鹿島出版, 1986.

17）松岡昌志，翠川三郎：国土数値情報を利用した地盤の平 均 S 波速度の推定, 日本建築学会構造系論文報告集, 第 443 号, pp. $65 \sim 71,1993$

18）長橋純男：関東地方周辺域における地震動短周期成分の 距離減衰特性, 第 8 回日本地震工学シンポジウム論文集, Vol. 1, pp. 283 288, 1990.

19）木下繁夫：南関東における強震動特性一 $1 / Q_{s}(f)$ 一，地震 学会講演予稿集, No. 2, p. 121, 1992.

20) Shima, E. : Seismic Microzoning Map of Tokyo, Proc. Second International Conf. Microzonation, Vol.1, pp. $433 \sim 443,1978$.

21）翠川三郎：地震断層と地盤条件を考虑した地表面最大加 速度・最大速度分布の推定，第 8 回地盤震動シンポジウ 么資料集，pp. 59 64，1980.

22) Joyner, W. B. and Fumal, T.E. : Use of Measured Shear-wave Velocity for Predicting Geologic Site Effects on Strong Ground Motion, Proc. Eighth WCEE, Vol. 2, pp. 777 783, 1984.

23) Borcherdt, R. et al. : Methodology for Predictive GIS Mapping of Special Study Zones for Strong Ground Shaking in the San Francisco Bay Region, CA, Proc. Fourth International Conf. Seismic Zonation, Vol.3, pp. 545 552, 1991.

24) Takemura, M. et al. : Site Amplification of Swaves from Strong Motion Records in Special Relation to Surface Geology, J. Phys. Earth, Vol. 39, pp.537 $552,1991$.

（1992 年 9 月 7 日原稿受理，1993 年 2 月 8 日採用決定） 